\title{
IN-SITU IDENTIFICATION OF GROUNDWATER DRAINAGE CONDITIONS IN A SELECTED SECTION WITHIN THE PARSETA RIVER VALLEY
}

\author{
Marek Marciniak, Lukasz Chudziak
}

\begin{abstract}
Drainage of groundwater by surface water, i.e. groundwater inflow into a stream or lake, is an essential component of the water balance. Moreover, the drainage and its spatial distribution determine geomorphological processes taking place in the riverbed. In order to identify the spatial distribution of groundwater inflow into the river, prototypes of two new meters filtrometer and gradientmeter) were designed and developed. The filtrometer allows to directly measure the groundwater-surface water seepage through bottom sediments at the place where the meter is embedded into the riverbed. The gradientmeter allows to measure hydraulic gradient within bottom sediments between groundwater and the river. Both parameters measured directly in the riverbed allow to specify the conditions of groundwater flow through bottom sediments. The field research studies conducted by means of the specified meters (filtrometer and gradientmeter) within the Parsęta River valley at Storkowo were aimed to investigate the drainage of groundwater and its conditions. A section of the Parsęta River with a length of 1600 meters and having no tributaries was selected. Three series of field measurements: spring, summer and autumn ones were conducted. During each series approximately 30 measurements were made by means of the filtrometer and the gradientmeter. The conducted measurements made it possible to calculate flow rates of the drainage of groundwater within the examined section of the Parsęta. The obtained results were verified on the basis of control measurements with the application of the differential river flow method. Moreover, it was possible to assess the spatial distribution of specific discharge, hydraulic gradient and hydraulic conductivity in bottom sediments of the Parsęta. On an annual basis, the largest drainage of groundwater was found within meander erosive areas where it reached nearly $150 \%$ of the average value for the examined section within the Parsęta valley. Within meander accumulative areas, the drainage level was at approximately $110 \%$ of the average value. At straight sections the drainage of groundwater was the lowest and amounted about $66 \%$ of the average value. The research studies conducted in the Parsęta valley confirmed the usefulness of the new method to assess the drainage of groundwater and its conditions within the river.
\end{abstract}


Keywords: river, drainage, groundwater inflow, filtrometer, gradientmeter, hydraulic conductivity

\section{Aim of research}

Interactions between surface water and groundwater in the hyporheic zone are a relevant element of the water-cycle balance and have a significant impact on the course of the riverbed processes (Kalbus et al. 2006). Groundwater inflows reaching - through sediments - the riverbed are heterogeneous and their spatial distribution has been poorly recognized so far (Sanders 1998; Wolf et al. 1991). The intensity and direction of water flow depends on the hydraulic parameters of bottom sediments as well as the hydraulic gradient between anaquifer and a river.

The field studies conducted within the Parsęta River valley at Storkowo were aimed to experimentally identify the spatial distribution of hydraulic parameters determining the intensity of groundwater drainage by the Parsęta River (i.e. the inflow of groundwater into the river) within the examined river section (Chudziak 2014).

\section{Measuring instruments}

Two new measuring devices: thefiltrometer and the gradientmeter, designed and constructed for measurements in the hyporheic zone (Marciniak, Chudziak 2015), were used to carry out out the research.

\section{Filtrometer}

The most important element of the filtrometer (Fig. 1) is a dome-shaped chamber (1). It is made of a steel pipe with a diameter of $34 \mathrm{~cm}$ and a height of $30 \mathrm{~cm}$ with a tightly-welded ellipsoidal lid, to which a bracket is attached (5). The dome-shaped chamber is embedded at some specified depth, in the bottom of a stream or water reservoir. This depth can be regulated (limited) by a sieve made of perforated sheet-metal (2) mounted inside the chamber. This sieve is not visible when placing the chamber in sediments, thus a rim (3) is mounted outside the chamber at the level of the sieve, allowing to measure the depth at which the chamber is embedded into sediments. This rim (3) can be fed with water which - flowing under pressure through holes within the rim circumference - facilitates aking the filtrometer out of the riverbed or reservoir bottom. The sieve (2) simultaneously serves as a pressing unit which consolidates sediments disturbed when installing 


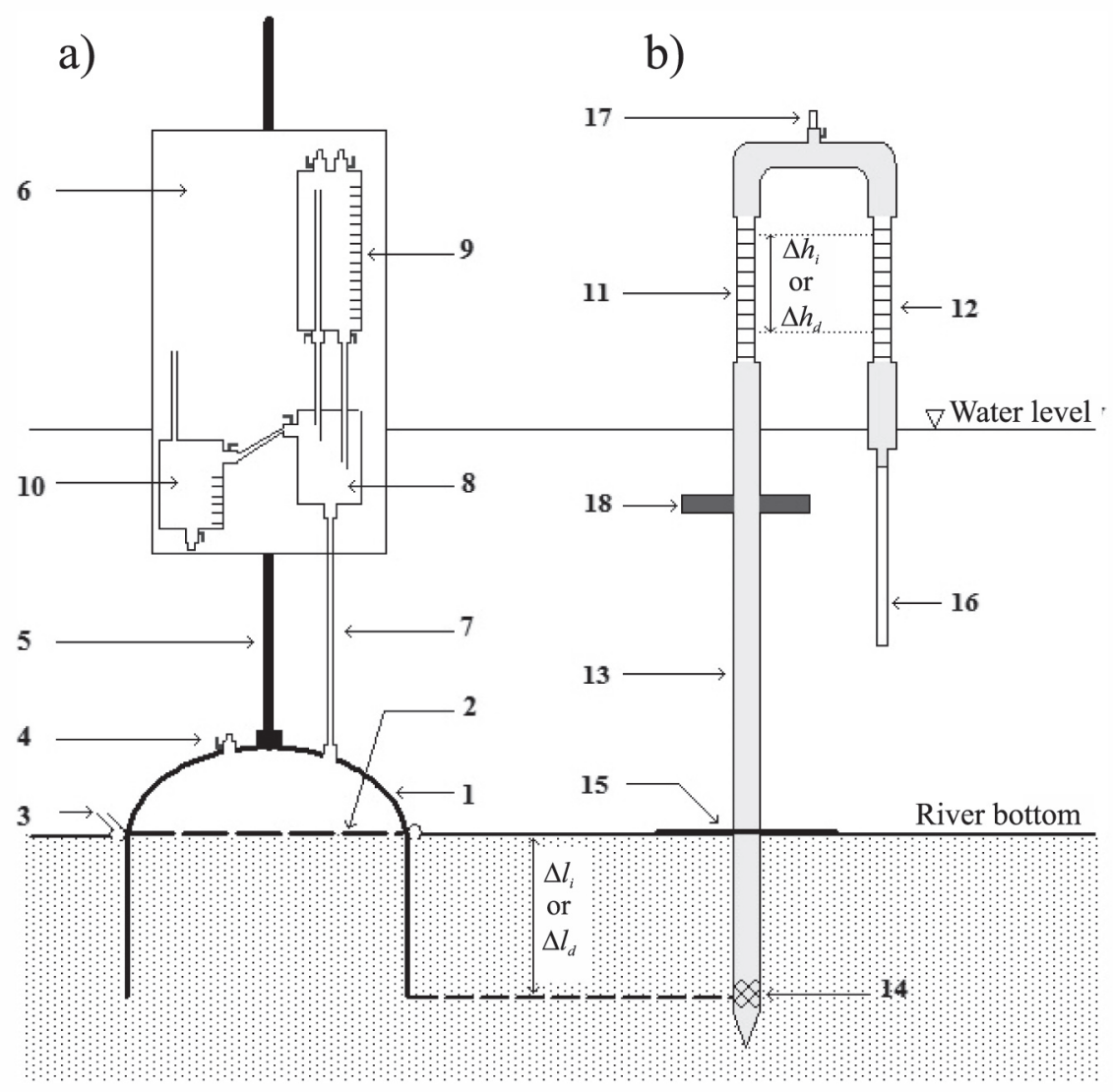

Fig. 1. Construction of filtrometer (a) and gradientmeter (b)

Explanations: 1 - dome-shaped chamber, 2-pressure sieve, 3 -rim/ perforated pipe with water supply, 4 - vent valve, 5 - bracket, 6 - movable plate, 7 - hose, 8 - reservoir, 9 - measuring tank for infiltration, 10 - measuring tank for drainage, 11 - piezometer measuring tube, 12 - measuring tube for surface waters, 13 - piezometer embedded into bottom sediments, 14 - screen, 15 - pressure ring, 16 - hose submerged in surface waters, 17 - valve, 18 - handle.

Source: authors' own study. 
the dome-shaped chamber. Outside the chamber there is a vent valve (4) which, when the chamber is embedded, is open to prevent producing excess pressure. The measuring set consists of a movable plate (6) at which a tank is mounted (8), connected by a hose (7) with the chamber (1). The plate is equipped with a tank (cylinder) to measure infiltration (9) and a tank to measure drainage (10). All measuring tanks are made of Plexiglas pipes with an internal diameter of $4 \mathrm{~cm}$ (Isiorho, Meyer 1999; Chudziak 2014).

The flux density of water drainage, i.e. the specific discharge $q_{d}$ in the domeshaped chamber with its specified surface $F$ and at specified time $t_{d}$ can be determined through measuring the level (volume) of water $V_{d}$ in the tank (10) (Baxter et al. 2003; Janik et al. 1989).

$$
q_{d}=\frac{V_{d}}{F t_{d}}
$$

Similarly, it is possible to determine the flux density of water infiltration $q_{i}$ in the chamber with its specified surface $F$ and at specified time $t_{i}$ through measuring the level (volume) of water $V_{i}$ in the tank (9).

$$
q_{i}=\frac{V_{i}}{F t_{i}}
$$

As a result of a single measurement, it is possible to obtain the level of flux density of water drainage or infiltration at a specific point where the dome-shaped chamber was embedded into bottom sediments. In order to recognize the spatial variability of drainage or infiltration, measuring tasks should be performed along several transverse profiles across a river, or at several measuring points located on the bottom of a water reservoir, at distances suited for the required accuracy of this hydrological recognition (Murdoch, Kelly 2003; Rosenberry 2008).

\section{Gradientmeter}

The hydraulic gradient between the aquifer and the river can be measured using the gradientmeter (Fig. 1b, Photo 1). It consists of two interconnected measuring pipes. Its longer pipe (13) is pressed into sediments to a depth which corresponds to the depth at which the dome-shaped chamber of the filtrometer was embedded. There is a screen in the lower part of the pipe (14) through which water from the aquifer flows inside. The hose (16) is attached to the shorter pipe of the gradientmeter which is placed in a river or water reservoir. To measure the difference in hydraulic head between a river and an aquifer, suction should be applied by sucking-in air 
through the valve (17). It will lead to a rise of water in both pipes up to the level of the calibrated measuring tubes (11) and (12) (Winter et al. 1988; Chudziak 2014).

When drainage takes place, the level of water in the pipe immersed in surface water is lower than in the pipe embedded in bottom sediments. Hydraulic gradient $i_{d}$ is calculated by dividing the difference in pressure $\Delta h_{d}$ by the depth $\Delta /$ at which gradientmeter is embedded into bottom sediments.

$$
i_{d}=\frac{\Delta h_{d}}{\Delta l}
$$

However, when infiltration is observed, the level of water in the pipe immersed in surface water is higher than in the pipe embedded into bottom sediments. Hydraulic gradient $i_{i}$ is calculated by dividing the difference in pressure $\Delta h_{i}$ by the depth $\Delta /$ at which the gradientmeter is embedded into bottom sediments.

$$
i_{i}=\frac{\Delta h_{i}}{\Delta l}
$$

Measurements made by means of the filtrometer and the gradientmeter allow to calculate hydraulic conductivity of bottom sediments making use of the following formulas:

$$
\begin{aligned}
& k_{d}=\frac{V_{d}}{F t_{d}} \cdot \frac{\Delta l}{\Delta h_{d}} \\
& k_{i}=\frac{V_{i}}{F t_{i}} \cdot \frac{\Delta l}{\Delta h_{i}}
\end{aligned}
$$

\section{Characteristics of the study area}

An upper section of the Parsęta River closed with a gauging station near Storkowo in the district of Stargard (powiat stargardzki) was selected for field measurements on the drainage of groundwater by surface waters.

Within this upper section, the river valley is narrow, flat-bottomed and has relatively gentle slopes. At some places the valley cuts into the moraine upland at a depth exceeding $30 \mathrm{~m}$. In this area, the Parsęta often changes its direction of flow 
- from latitudinal to meridional (Kaniecki 1994). Its development indicator within this area (at 1.57) allows to classify it as a meandering river. The river length from its spring to the hydrometric profile set to test the filtration parameters of bottom sediments is $15.34 \mathrm{~km}$, while the catchment area $-74.77 \mathrm{~km}^{2}$ (Fig. 2). The river gradient within this area reaches $4 \%$ on average and the catchment area slope 8.4\%o (Kostrzewski et al. 1994).

The Parsęta River is characterized by the ground-snow-rain regime of its supplies. The highest water level in the river is observed after spring snowmelts, from February to April. Starting from spring snowmelts, the river discharge decreases until autumn (Kostrzewski et al. 1994). Water level of the upper Parsęta has a little annual amplitude of fluctuations. Between 1951-1975 the amplitude was $111 \mathrm{~cm}$ (Kaniecki 1994) while between 1986-1993 it was $87 \mathrm{~cm}$ (Kostrzewski et al. 1994). Higher levels (compared to the average) persist from November to May, while lower ones occur in the summer months. The river average discharge for the hydrometric profile in Storkowo calculated for 1994-2004 amounted to $0.651 \mathrm{~m}^{3} \cdot \mathrm{s}^{-1}$, which stands for a specific discharge of $8.8 \mathrm{dm}^{3} \cdot \mathrm{s}^{-1} \cdot \mathrm{km}^{-2}$. The highest and lowest discharges observed during this period were $6.279 \mathrm{~m}^{3} \cdot \mathrm{s}^{-1}$ and $0.180 \mathrm{~m}^{3} \cdot \mathrm{s}^{-1}$ espectively. The coefficient of flow variation for the Parsęta, calculated

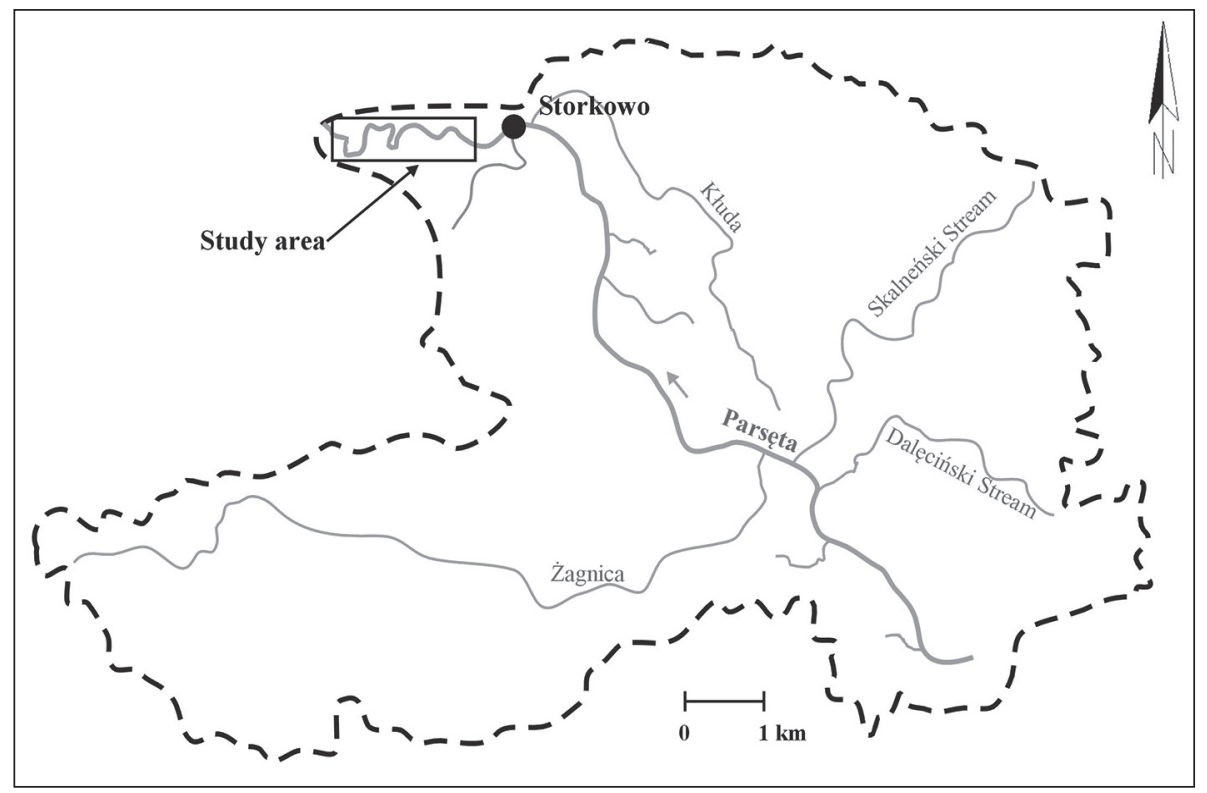

Fig. 2. Catchment of the upper Parsęta River (Kostrzewski et al. 1994 supplemented) Source: authors' own study. 
on the basis of the highest flow to the lowest flow, amounted to 34.8 (Szpikowski et al. 2006). The river is characterized by that its supply is overwhelmingly dominated by groundwater inflow (Kaniecki 1994; Kostrzewski et al. 1994). Due to the lithology of the area and extensive land declines, the upper Parsęta catchment has favorable conditions of the infiltration of precipitation waters (Choiński 1998) which feed the river through underground paths. Between 1986-1993 its groundwater recharge amounted up to $93.5 \%$ of the river runoff (Kaniecki 1994; Pociask-Karteczka 2003).

It should be noted that the Parsęta within its upper course is a river with highly dynamic fluvial transport. Bottom erosion and lateral erosion are the main processes which determine the intensity of fluvial transport as well as the type and origin of transported material. At low water levels there is an increase in the intensity of bottom erosion which leads to the elution of substrate material and deepening of the riverbed. At high levels, there is an increase in the amount of transported material originating from the destruction of the riverbed banks due to increased lateral erosion (Kostrzewski et al. 1994).

\section{Research methodology}

To measure the drainage of groundwater by the river, a section of the Parsęta River with a length of $1580 \mathrm{~m}$ measured in the main current was selected in the north-western part of the upper Parsęta catchment, near Storkowo. Attempts were made to select such a section within the river which is characterized by a diverse course (i.e. with straight stretches and meanders). Moreover, a section with no tributaries was sought. Fourteen morphometric profiles (from PM_1 to PM_14) were set on the river where measurements on the drainage were made by means of the filtrometer and the gradientmeter (Fig. 3).

These morphometric profiles were set at straight stretches of the river as well as its meanders. It was decided to thoroughly examine the intensity of drainage within a selected meander, where nine morphometric profiles were located (from PM_3 to PM_11). At the profiles two up to three measurements of the drainage were planned to be made by means of the filtrometer and the gradientmeter depending on the river width and capability to embed the filtrometer dome-shaped chamber into the river bottom. The PM_1 and PM_12 outermost profiles fulfilled the additional function of hydrometric profiles at which measurements of river discharge were conducted with the application of an electromagnetic current meter made by SEBA Hydrometrie.

On the basis of the laboratory tests it was determined that the optimal depth of embedding thea filtrometer and the gradientmeter into bottom sediments 


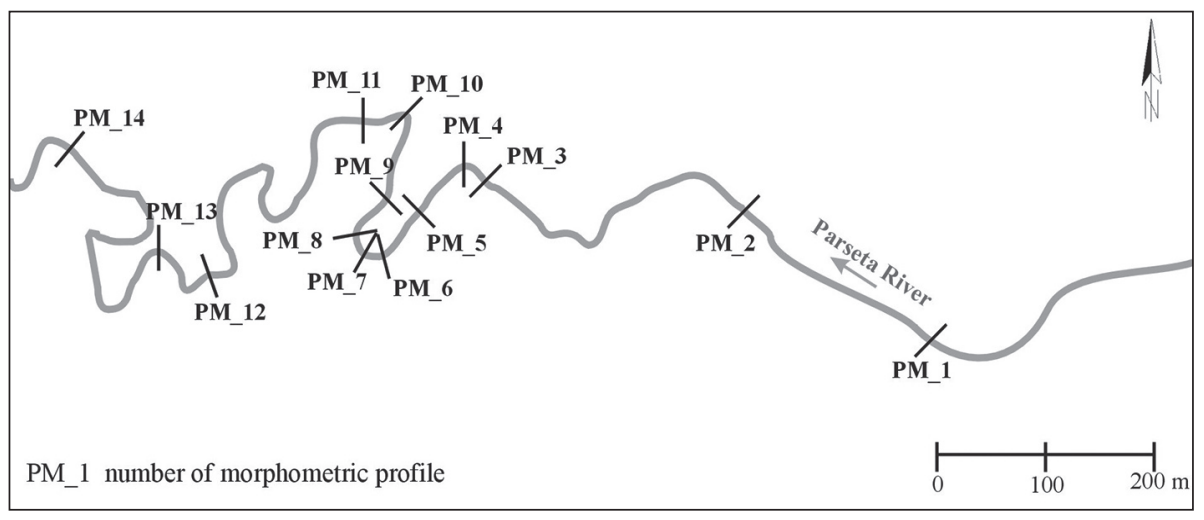

Fig. 3. Location of morphometric profiles in the selected section of the Parsęta River Source: authors' own study.

should be $20 \mathrm{~cm}$. In order to confirm the above depth in field conditions, four series of measurements were conducted taking into consideration dependencies of measurement depths on the hydraulic gradients, which was covered in detail in a paper by Chudziak (2014).

The stabilization of filtration conditions inside the filtrometer chamber depends on the type of bottom sediments as well as the dimensions of the chamber and its depth of embedding into the bottom. Therefore, stabilization times should be defined individually for any river or water reservoir. On the basis of field tests (Chudziak 2014) it was found that the stabilization of filtration conditions when measuring the drainage of groundwater by the Parsęta River - should take 20 minutes at least.

Three series of measurements were conducted on the drainage of groundwater by the Parsęta river at various times of the year. The first series was taken in spring, the second one - in summer, while the third one - in autumn 2012.

Due to the location of the measurement points within parts of the river characterized by some diverse fluvial processes, for each series, the measuring points are divided into three groups (Tab. 1, 2, 3; Fig. 7):

- points located within meander erosive areas (dark grey);

- points located within meander accumulative area (light grey);

- points located at straight sections of the river (white). 
Table 1. Results of the spring series of measurements of drainage in the Parsęta River

\begin{tabular}{|c|c|c|c|c|c|c|c|c|c|c|c|}
\hline No. & Profile & $\begin{array}{c}V_{d} \\
{\left[\mathrm{~cm}^{3}\right]}\end{array}$ & $\begin{array}{c}t_{d} \\
{[\mathrm{~s}]}\end{array}$ & $\begin{array}{c}F \\
{\left[\mathrm{~cm}^{2}\right]}\end{array}$ & $\begin{array}{c}Q_{d} \\
{\left[\mathrm{~cm}^{3} / \mathrm{s}\right]}\end{array}$ & $\begin{array}{c}q_{d} \\
{\left[\mathrm{~cm}^{3} / \mathrm{s} / \mathrm{cm}^{2}\right]}\end{array}$ & $\begin{array}{c}\Delta h_{d} \\
{\left[\mathrm{~cm}^{3}\right]}\end{array}$ & $\begin{array}{c}\Delta i_{d} \\
{[\mathrm{~cm}]}\end{array}$ & $\begin{array}{c}i_{d} \\
{[\mathrm{~cm} / \mathrm{cm}]}\end{array}$ & $\begin{array}{c}k_{d} \\
{[\mathrm{~cm} / \mathrm{s}]}\end{array}$ & $\begin{array}{c}k_{10 d} \\
{[\mathrm{~m} / \mathrm{s}]}\end{array}$ \\
\hline 1 & PM_1 & 69.0 & 120 & \multirow{30}{*}{913.27} & 0.58 & $6.30 \mathrm{E}-04$ & 1.1 & \multirow{30}{*}{20.0} & 0.055 & 1.14E-02 & $1.06 \mathrm{E}-04$ \\
\hline 2 & PM_1 & 52.0 & 120 & & 0.43 & 4.74E-04 & 0.9 & & 0.045 & $1.05 \mathrm{E}-02$ & $9.71 \mathrm{E}-05$ \\
\hline 3 & PM_2 & 90.0 & 120 & & 0.75 & $8.21 \mathrm{E}-04$ & 1.4 & & 0.070 & 1.17E-02 & $1.08 \mathrm{E}-04$ \\
\hline 4 & PM_2 & 87.0 & 120 & & 0.73 & 7.94E-04 & 1.4 & & 0.070 & 1.13E-02 & $1.04 \mathrm{E}-04$ \\
\hline 5 & PM_3 & 97.0 & 120 & & 0.81 & 8.85E-04 & 1.9 & & 0.095 & 9.32E-03 & $8.51 E-05$ \\
\hline 6 & PM_3 & 91.0 & 120 & & 0.76 & 8.30E-04 & 1.8 & & 0.090 & $9.23 \mathrm{E}-03$ & $8.43 E-05$ \\
\hline 7 & PM_4 & 82.0 & 30 & & 2.73 & 2.99E-03 & 6.8 & & 0.340 & 8.80E-03 & 7.94E-05 \\
\hline 8 & PM_4 & 56.0 & 30 & & 1.87 & 2.04E-03 & 3.1 & & 0.155 & $1.32 \mathrm{E}-02$ & 1.19E-04 \\
\hline 9 & PM_5 & 80.0 & 120 & & 0.67 & 7.30E-04 & 1.5 & & 0.075 & $9.73 \mathrm{E}-03$ & $9.21 \mathrm{E}-05$ \\
\hline 10 & PM_5 & 79.0 & 120 & & 0.66 & 7.21E-04 & 1.4 & & 0.070 & $1.03 \mathrm{E}-02$ & $9.72 \mathrm{E}-05$ \\
\hline 11 & PM_6 & 84.0 & 120 & & 0.70 & $7.66 \mathrm{E}-04$ & 1.5 & & 0.075 & $1.02 \mathrm{E}-02$ & $9.46 \mathrm{E}-05$ \\
\hline 12 & PM_6 & 62.0 & 120 & & 0.52 & $5.66 \mathrm{E}-04$ & 1.0 & & 0.050 & 1.13E-02 & $1.04 \mathrm{E}-04$ \\
\hline 13 & PM_7 & 94.0 & 45 & & 2.09 & 2.29E-03 & 17.7 & & 0.885 & $2.58 \mathrm{E}-03$ & 2.35E-05 \\
\hline 14 & PM_7 & 69.0 & 45 & & 1.53 & $1.68 \mathrm{E}-03$ & 4.8 & & 0.240 & 7.00E-03 & $6.34 \mathrm{E}-05$ \\
\hline 15 & PM_8 & 62.0 & 90 & & 0.69 & $7.54 \mathrm{E}-04$ & 1.2 & & 0.060 & $1.26 \mathrm{E}-02$ & 1.10E-04 \\
\hline 16 & PM_8 & 84.0 & 90 & & 0.93 & $1.02 \mathrm{E}-03$ & 2.0 & & 0.100 & $1.02 \mathrm{E}-02$ & 8.93E-05 \\
\hline 17 & PM_8 & 68.0 & 90 & & 0.76 & 8.27E-04 & 1.3 & & 0.065 & $1.27 \mathrm{E}-02$ & 1.11E-04 \\
\hline 18 & PM_9 & 50.0 & 120 & & 0.42 & $4.56 \mathrm{E}-04$ & 0.8 & & 0.040 & $1.14 \mathrm{E}-02$ & $9.82 \mathrm{E}-05$ \\
\hline 19 & PM_9 & 134.0 & 90 & & 1.49 & $1.63 \mathrm{E}-03$ & 2.8 & & 0.140 & 1.16E-02 & $1.00 \mathrm{E}-04$ \\
\hline 20 & PM_9 & 136.0 & 45 & & 3.02 & 3.31E-03 & 10.1 & & 0.505 & $6.55 \mathrm{E}-03$ & 5.61E-05 \\
\hline 21 & PM_10 & 64.0 & 90 & & 0.71 & 7.79E-04 & 2.3 & & 0.115 & $6.77 \mathrm{E}-03$ & 6.37E-05 \\
\hline 22 & PM_10 & 55.0 & 90 & & 0.61 & $6.69 \mathrm{E}-04$ & 2.0 & & 0.100 & $6.69 \mathrm{E}-03$ & $6.30 \mathrm{E}-05$ \\
\hline 23 & PM_11 & 48.0 & 120 & & 0.40 & 4.38E-04 & 0.5 & & 0.025 & $1.75 \mathrm{E}-02$ & 1.61E-04 \\
\hline 24 & PM_11 & 89.0 & 120 & & 0.74 & 8.12E-04 & 1.3 & & 0.065 & $1.25 \mathrm{E}-02$ & $1.15 \mathrm{E}-04$ \\
\hline 25 & PM_12 & 72.0 & 60 & & 1.20 & $1.31 \mathrm{E}-03$ & 2.5 & & 0.125 & $1.05 \mathrm{E}-02$ & $9.61 \mathrm{E}-05$ \\
\hline 26 & PM_12 & 44.0 & 90 & & 0.49 & 5.35E-04 & 1.4 & & 0.070 & $7.65 \mathrm{E}-03$ & $6.95 \mathrm{E}-05$ \\
\hline 27 & PM_13 & 61.0 & 90 & & 0.68 & 7.42E-04 & 0.8 & & 0.040 & 1.86E-02 & 1.64E-04 \\
\hline 28 & PM_13 & 72.0 & 60 & & 1.20 & $1.31 E-03$ & 3.6 & & 0.180 & 7.30E-03 & $6.45 \mathrm{E}-05$ \\
\hline 29 & PM_14 & 48.0 & 120 & & 0.40 & 4.38E-04 & 1.4 & & 0.070 & $6.26 \mathrm{E}-03$ & 5.47E-05 \\
\hline 30 & PM_14 & 39.0 & 120 & & 0.33 & 3.56E-04 & 1.1 & & 0.055 & $6.47 \mathrm{E}-03$ & 5.65E-05 \\
\hline \multicolumn{6}{|c|}{ Average values } & $1.05 \mathrm{E}-03$ & & & 0.136 & $1.01 \mathrm{E}-02$ & $9.11 \mathrm{E}-05$ \\
\hline
\end{tabular}

where: $Q_{d}=V d / t_{d}$ and $k_{10}$ is hydraulic conductivity in temperature $10^{\circ} \mathrm{C}$.

Source: authors' own study. 
Table 2. Results of the summer series of measurements of drainage in the Parsęta River

\begin{tabular}{|c|c|c|c|c|c|c|c|c|c|c|c|}
\hline No. & Profile & $\begin{array}{c}V_{d} \\
{\left[\mathrm{~cm}^{3}\right]}\end{array}$ & $\begin{array}{c}t_{d} \\
{[\mathrm{~s}]}\end{array}$ & $\begin{array}{c}F \\
{\left[\mathrm{~cm}^{2}\right]}\end{array}$ & $\begin{array}{c}Q_{d} \\
{\left[\mathrm{~cm}^{3} / \mathrm{s}\right]}\end{array}$ & $\begin{array}{c}q_{d} \\
{\left[\mathrm{~cm}^{3} / \mathrm{s} / \mathrm{cm}^{2}\right]}\end{array}$ & $\begin{array}{c}\Delta h_{d} \\
{\left[\mathrm{~cm}^{3}\right]}\end{array}$ & $\begin{array}{c}\Delta i_{d} \\
{[\mathrm{~cm}]}\end{array}$ & $\begin{array}{c}i_{d} \\
{[\mathrm{~cm} / \mathrm{cm}]}\end{array}$ & $\begin{array}{c}k_{d} \\
{[\mathrm{~cm} / \mathrm{s}]}\end{array}$ & $\begin{array}{c}k_{10 d} \\
{[\mathrm{~m} / \mathrm{s}]}\end{array}$ \\
\hline 1 & PM_1 & 42.0 & 60 & & 0.70 & 7.66E-04 & 1.3 & & 0.065 & 1.18E-02 & $1.05 \mathrm{E}-04$ \\
\hline 2 & PM_1 & 47.0 & 60 & & 0.78 & $8.58 \mathrm{E}-04$ & 1.3 & & 0.065 & 1.32E-02 & 1.17E-04 \\
\hline 3 & PM_1 & 41.0 & 60 & & 0.68 & 7.48E-04 & 1.2 & & 0.060 & $1.25 \mathrm{E}-02$ & $1.11 \mathrm{E}-04$ \\
\hline 4 & PM_3 & 83.0 & 45 & & 1.84 & 2.02E-03 & 7.7 & & 0.385 & $5.25 \mathrm{E}-03$ & $4.58 \mathrm{E}-05$ \\
\hline 5 & PM_3 & 38.0 & 70 & & 0.54 & $5.94 \mathrm{E}-04$ & 1.0 & & 0.050 & 1.19E-02 & $1.04 \mathrm{E}-04$ \\
\hline 6 & PM_4 & 65.0 & 30 & & 2.17 & $2.37 \mathrm{E}-03$ & 3.1 & & 0.155 & $1.53 \mathrm{E}-02$ & 1.34E-04 \\
\hline 7 & PM_4 & 53.0 & 20 & & 2.65 & $2.90 \mathrm{E}-03$ & 6.2 & & 0.310 & $9.36 \mathrm{E}-03$ & 8.18E-05 \\
\hline 8 & PM_5 & 43.0 & 60 & & 0.72 & 7.85E-04 & 1.7 & & 0.085 & 9.23E-03 & 8.11E-05 \\
\hline 9 & PM_5 & 40.0 & 60 & & 0.67 & 7.30E-04 & 1.2 & & 0.060 & 1.22E-02 & $1.07 \mathrm{E}-04$ \\
\hline 10 & PM_6 & 52.0 & 20 & & 2.60 & 2.85E-03 & 10.4 & & 0.520 & 5.47E-03 & 5.04E-05 \\
\hline 11 & PM_6 & 70.0 & 15 & & 4.67 & $5.11 \mathrm{E}-03$ & 4.1 & & 0.205 & $2.49 \mathrm{E}-02$ & 2.30E-04 \\
\hline 12 & PM_7 & 56.0 & 20 & & 2.80 & 3.07E-03 & 4.0 & & 0.200 & $1.53 \mathrm{E}-02$ & 1.40E-04 \\
\hline 13 & PM_7 & 58.0 & 60 & & 0.97 & 1.06E-03 & 1.5 & & 0.075 & $1.41 \mathrm{E}-02$ & $1.29 \mathrm{E}-04$ \\
\hline 14 & PM_8 & 51.0 & 60 & 913.27 & 0.85 & $9.31 E-04$ & 2.0 & 20.0 & 0.100 & $9.31 E-03$ & 8.39E-05 \\
\hline 15 & PM_8 & 42.0 & 60 & & 0.70 & 7.66E-04 & 1.3 & & 0.065 & $1.18 \mathrm{E}-02$ & $1.06 \mathrm{E}-04$ \\
\hline 16 & PM_9 & 59.0 & 60 & & 0.98 & $1.08 \mathrm{E}-03$ & 3.4 & & 0.170 & $6.33 \mathrm{E}-03$ & $5.68 \mathrm{E}-05$ \\
\hline 17 & PM_9 & 87.0 & 20 & & 4.35 & 4.76E-03 & 10.9 & & 0.545 & $8.74 \mathrm{E}-03$ & $7.84 \mathrm{E}-05$ \\
\hline 18 & PM_10 & 80.0 & 60 & & 1.33 & $1.46 \mathrm{E}-03$ & 2.4 & & 0.120 & $1.22 \mathrm{E}-02$ & 1.10E-04 \\
\hline 19 & PM_10 & 96.0 & 60 & & 1.60 & $1.75 \mathrm{E}-03$ & 2.5 & & 0.125 & 1.40E-02 & 1.26E-04 \\
\hline 20 & PM_11 & 30.0 & 600 & & 0.05 & 5.47E-05 & 0.5 & & 0.025 & $2.19 \mathrm{E}-03$ & 2.03E-05 \\
\hline 21 & PM_11 & 56.0 & 300 & & 0.19 & 2.04E-04 & 1.3 & & 0.065 & $3.14 \mathrm{E}-03$ & $2.91 \mathrm{E}-05$ \\
\hline 22 & PM_12 & 61.0 & 60 & & 1.02 & $1.11 \mathrm{E}-03$ & 3.1 & & 0.155 & 7.18E-03 & $6.51 \mathrm{E}-05$ \\
\hline 23 & PM_12 & 36.0 & 60 & & 0.60 & $6.57 \mathrm{E}-04$ & 1.4 & & 0.070 & $9.39 \mathrm{E}-03$ & $8.51 \mathrm{E}-05$ \\
\hline 24 & PM_13 & 41.0 & 300 & & 0.14 & $1.50 \mathrm{E}-04$ & 0.4 & & 0.020 & $7.48 \mathrm{E}-03$ & $6.75 \mathrm{E}-05$ \\
\hline 25 & PM_13 & 50.0 & 180 & & 0.28 & 3.04E-04 & 0.8 & & 0.040 & 7.60E-03 & $6.86 \mathrm{E}-05$ \\
\hline 26 & PM_14 & 56.0 & 180 & & 0.31 & $3.41 \mathrm{E}-04$ & 1.4 & & 0.070 & $4.87 \mathrm{E}-03$ & $6.55 \mathrm{E}-05$ \\
\hline 27 & PM_14 & 43.0 & 120 & & 0.36 & $3.92 \mathrm{E}-04$ & 1.1 & & 0.055 & 7.13E-03 & $6.40 \mathrm{E}-05$ \\
\hline \multicolumn{6}{|c|}{ Average values } & $1.34 \mathrm{E}-03$ & & & 0.143 & $1.01 \mathrm{E}-02$ & $9.03 \mathrm{E}-05$ \\
\hline
\end{tabular}

Source: authors' own study. 
Table 3. Results of the autumn series of measurements of drainage in the Parsęta River

\begin{tabular}{|c|c|c|c|c|c|c|c|c|c|c|c|}
\hline No. & Profile & $\begin{array}{c}V_{d} \\
{\left[\mathrm{~cm}^{3}\right]}\end{array}$ & $\begin{array}{c}t_{d} \\
{[\mathrm{~s}]}\end{array}$ & $\begin{array}{c}F \\
{\left[\mathrm{~cm}^{2}\right]}\end{array}$ & $\begin{array}{c}Q_{d} \\
{\left[\mathrm{~cm}^{3} / \mathrm{s}\right]}\end{array}$ & $\begin{array}{c}q_{d} \\
{\left[\mathrm{~cm}^{3} / \mathrm{s} / \mathrm{cm}^{2}\right]}\end{array}$ & $\begin{array}{c}\Delta h_{d} \\
{\left[\mathrm{~cm}^{3}\right]}\end{array}$ & $\begin{array}{c}\Delta i_{d} \\
{[\mathrm{~cm}]}\end{array}$ & $\begin{array}{c}i_{d} \\
{[\mathrm{~cm} / \mathrm{cm}]}\end{array}$ & $\begin{array}{c}k_{d} \\
{[\mathrm{~cm} / \mathrm{s}]}\end{array}$ & $\begin{array}{c}k_{10 d} \\
{[\mathrm{~m} / \mathrm{s}]}\end{array}$ \\
\hline 1 & PM_1 & 79.0 & 90 & \multirow{28}{*}{913.27} & 0.88 & $9.61 \mathrm{E}-04$ & 1.4 & \multirow{28}{*}{20.0} & 0.070 & $1.37 \mathrm{E}-02$ & 1.60E-04 \\
\hline 2 & PM_1 & 73.0 & 90 & & 0.81 & 8.88E-04 & 1.2 & & 0.060 & $1.48 \mathrm{E}-02$ & $1.72 \mathrm{E}-04$ \\
\hline 3 & PM_3 & 61.0 & 60 & & 1.02 & $1.11 \mathrm{E}-03$ & 7.9 & & 0.395 & 2.82E-03 & $3.14 \mathrm{E}-05$ \\
\hline 4 & PM_3 & 51.0 & 60 & & 0.85 & $9.31 \mathrm{E}-04$ & 1.8 & & 0.090 & $1.03 \mathrm{E}-02$ & 1.15E-04 \\
\hline 5 & PM_4 & 71.0 & 60 & & 1.18 & 1.30E-03 & 1.5 & & 0.075 & $1.73 \mathrm{E}-02$ & $1.95 \mathrm{E}-04$ \\
\hline 6 & PM_4 & 57.0 & 60 & & 0.95 & $1.04 \mathrm{E}-03$ & 1.0 & & 0.050 & $2.08 \mathrm{E}-02$ & $2.35 \mathrm{E}-04$ \\
\hline 7 & PM_4 & 68.0 & 60 & & 1.13 & $1.24 \mathrm{E}-03$ & 3.4 & & 0.170 & 7.30E-03 & $8.20 \mathrm{E}-05$ \\
\hline 8 & PM_5 & 42.0 & 120 & & 0.35 & 3.83E-04 & 1.4 & & 0.070 & $5.47 \mathrm{E}-03$ & $6.13 \mathrm{E}-05$ \\
\hline 9 & PM_5 & 68.0 & 300 & & 0.23 & 2.48E-04 & 7.5 & & 0.375 & $6.62 \mathrm{E}-04$ & $7.41 \mathrm{E}-06$ \\
\hline 10 & PM_6 & 59.0 & 60 & & 0.98 & $1.08 \mathrm{E}-03$ & 8.6 & & 0.430 & $2.50 \mathrm{E}-03$ & 2.80E-05 \\
\hline 11 & PM_6 & 55.0 & 300 & & 0.18 & 2.01E-04 & 1.1 & & 0.055 & $3.65 \mathrm{E}-03$ & 4.07E-05 \\
\hline 12 & PM_7 & 104.0 & 60 & & 1.73 & $1.90 \mathrm{E}-03$ & 5.7 & & 0.285 & $6.66 \mathrm{E}-03$ & 7.43E-05 \\
\hline 13 & PM_7 & 69.0 & 120 & & 0.58 & $6.30 \mathrm{E}-04$ & 0.9 & & 0.045 & $1.40 \mathrm{E}-02$ & $1.56 \mathrm{E}-04$ \\
\hline 14 & PM_8 & 61.0 & 60 & & 1.02 & $1.11 \mathrm{E}-03$ & 1.8 & & 0.090 & $1.24 \mathrm{E}-02$ & 1.40E-04 \\
\hline 15 & PM_8 & 52.0 & 60 & & 0.87 & $9.49 \mathrm{E}-04$ & 1.3 & & 0.065 & $1.46 \mathrm{E}-02$ & 1.65E-04 \\
\hline 16 & PM_9 & 60.0 & 90 & & 0.67 & 7.30E-04 & 1.4 & & 0.070 & $1.04 \mathrm{E}-02$ & 1.17E-04 \\
\hline 17 & PM_9 & 52.0 & 90 & & 0.58 & $6.33 \mathrm{E}-04$ & 1.5 & & 0.075 & $8.44 \mathrm{E}-03$ & $9.47 \mathrm{E}-05$ \\
\hline 18 & PM_9 & 57.0 & 90 & & 0.63 & $6.93 \mathrm{E}-04$ & 1.5 & & 0.075 & $9.25 \mathrm{E}-03$ & 1.04E-04 \\
\hline 19 & PM_10 & 83.0 & 60 & & 1.38 & $1.51 \mathrm{E}-03$ & 3.0 & & 0.150 & $1.01 \mathrm{E}-02$ & 1.13E-04 \\
\hline 20 & PM_10 & 97.0 & 60 & & 1.62 & $1.77 \mathrm{E}-03$ & 4.0 & & 0.200 & 8.85E-03 & $9.91 \mathrm{E}-05$ \\
\hline 21 & PM_11 & 58.0 & 300 & & 0.19 & $2.12 \mathrm{E}-04$ & 1.4 & & 0.070 & $3.02 E-03$ & 3.39E-05 \\
\hline 22 & PM_11 & 70.0 & 300 & & 0.23 & $2.55 \mathrm{E}-04$ & 1.2 & & 0.060 & 4.26E-03 & 4.77E-05 \\
\hline 23 & PM_12 & 67.0 & 60 & & 1.12 & $1.22 \mathrm{E}-03$ & 1.7 & & 0.085 & $1.44 \mathrm{E}-02$ & $1.61 \mathrm{E}-04$ \\
\hline 24 & PM_12 & 82.0 & 60 & & 1.37 & $1.50 \mathrm{E}-03$ & 2.3 & & 0.115 & 1.30E-02 & $1.46 \mathrm{E}-04$ \\
\hline 25 & PM_13 & 65.0 & 120 & & 0.54 & $5.93 \mathrm{E}-04$ & 1.0 & & 0.050 & 1.19E-02 & $1.32 \mathrm{E}-04$ \\
\hline 26 & PM_13 & 53.0 & 120 & & 0.44 & 4.84E-04 & 5.2 & & 0.260 & 1.86E-03 & $2.07 \mathrm{E}-05$ \\
\hline 27 & PM_14 & 41.0 & 120 & & 0.34 & $3.74 \mathrm{E}-04$ & 3.9 & & 0.195 & $1.92 \mathrm{E}-03$ & $2.14 \mathrm{E}-05$ \\
\hline 28 & PM_14 & 67.0 & 120 & & 0.56 & $6.11 \mathrm{E}-04$ & 2.4 & & 0.120 & 5.09E-03 & $5.67 \mathrm{E}-05$ \\
\hline \multicolumn{6}{|c|}{ Average values } & $8.77 \mathrm{E}-04$ & & & 0.138 & $8.91 \mathrm{E}-03$ & 1.00E-04 \\
\hline
\end{tabular}

Source: authors' own study. 


\section{Results of measurements}

\section{Spring series of measurements}

In the spring season, thirty measurements on the drainage of groundwater by the Parsęta river were conducted from 28.04.2012 to 1.05.2012. Due to the river width, which - along the examined section - generally does not exceed $6.0 \mathrm{~m}$, and due to little depths of the river averaging 0.40 to $0.50 \mathrm{~m}$, three measurements were conducted only at two morphometric profiles (PM_8 and PM_9). As for the remaining twelve profiles, the measurements were conducted at two points. At each profile, the measuring process was started with probing the river depth. Points with a relatively flat bottom were selected. Due to the filtrometer design constraints, points where the river depth exceeded $0.32 \mathrm{~m}$ were selected. Moreover, attempts were made to select points with relatively uniform bottom sediments which allow to embed the filtrometer dome-shaped chamber at any required depth and reduce the likelihood of preferential flow paths (Brodie et al. 2009). After selecting measuring points, the filtrometer and the gradientmeter were placed on the river bottom. These instruments were embedded inte the riverbed at non-trodden places. Stepping on a thin layer of silt in the riverbed could potentially damage it and reduce filtration (Rosenberry, Morin 2004). After preparation of the measuring instruments, at each point, flow conditions inside the filtrometer chamber were stabilized for at least 20 minutes. Then measurements of the drainage were made. The following parameters were measured: level (volume) of water $V_{d}$ filtering through the filtrometer chamber at a time $t_{d}$, difference in water levels $\Delta h_{d}$ between the aquifer and the river, and water temperature $T$ (Photo 1 ). The results are presented in Tab. 1.

\section{Summer series of measurements}

Due to low water levels in the river in the summer season, twenty-seven measurements on the drainage of groundwater by the Parsęta River were conducted from 30.07.2012 to 1.08.2012. The methodology of selecting measuring points, stabilization of the instruments and measurements themselves were the same as during the spring series of measurements. The results are presented in Tab. 2.

\section{Autumn series of measurements}

In the autumn season, twenty eight measurements of the drainage of groundwater by the Parsęta River were conducted from 1.11.2012 to 4.11.2012. The methodology of measurements was the same as during the spring series of measurements. The results are presented in Tab. 3 . 


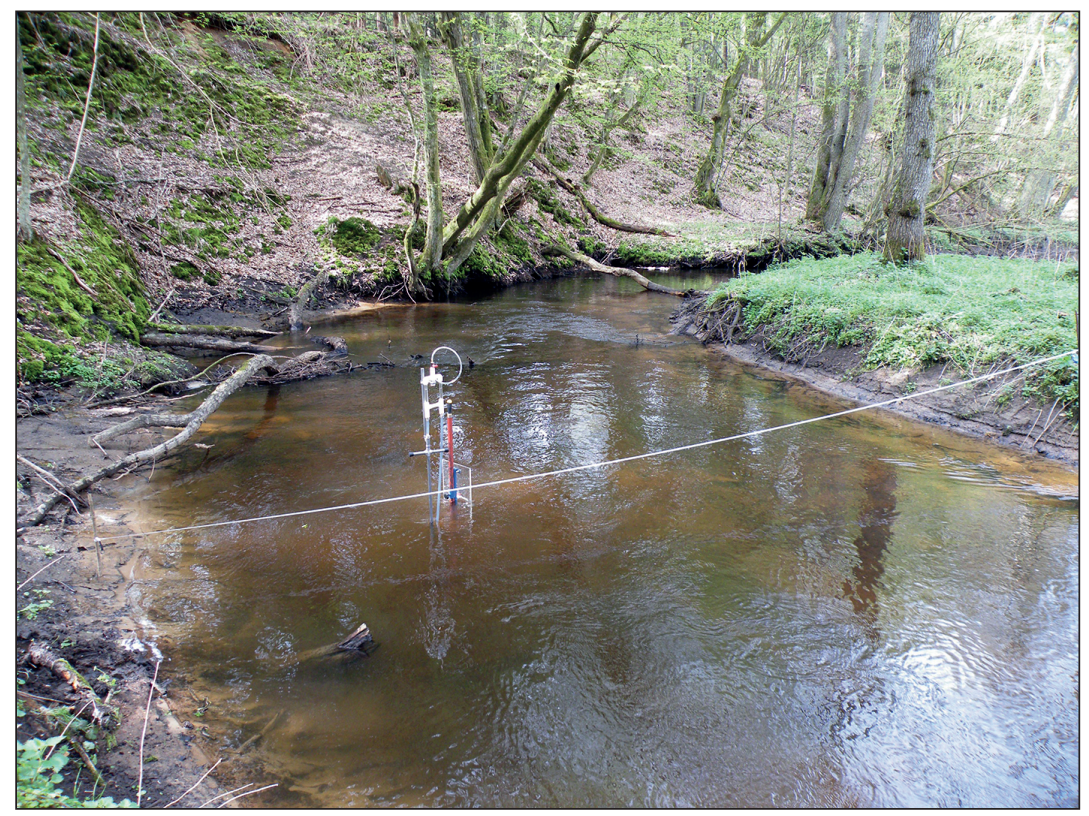

Photo 1. Measurements of drainage of the Parsęta River during the spring series of measurements (photo by $€$. Chudziak)

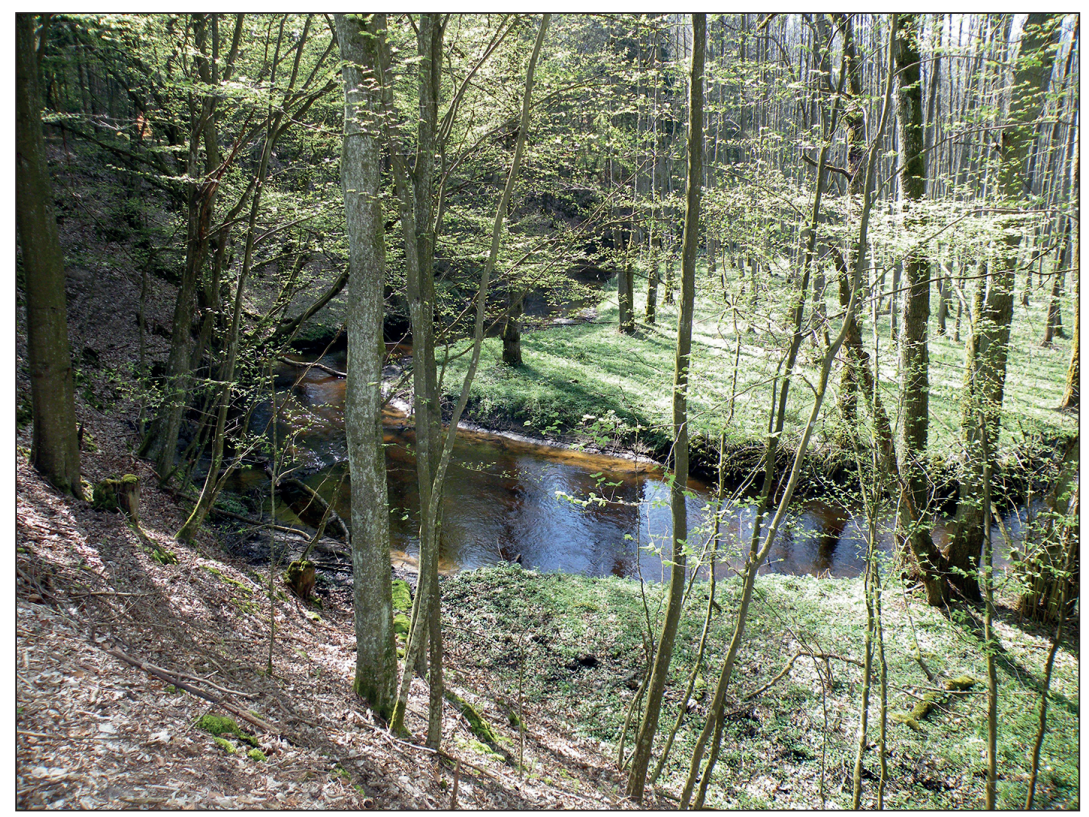

Photo 2. Land relief within the PM_7 morphometric profile area (photo by Ł. Chudziak) 


\section{Interpretation of results}

After the analysis of partial measurements a high changeability of the measured parameters was observed: within the morphometric profile, along the measurement section and in different parts of the year. During the spring series of measurements, the spread of the obtained values of specific discharge $q_{d}$ ranged from 3.56E-04 to $3.31 \mathrm{E}-03 \mathrm{~cm} \mathrm{~cm}^{3} \cdot \mathrm{s}^{-1} \cdot \mathrm{cm}^{-2}$. The distribution of hydraulic gradient values $i_{d}-$ to a large extent - reflects the distribution of specific discharge $q_{d}$. The obtained gradients ranged from $0.025 \mathrm{~cm}$ to $0.885 \mathrm{~cm}$. In the case of the obtained hydraulic conductivity $k_{10 d}$ the variability is considerably lower. The spread of the obtained values ranged from $2.35 \mathrm{E}-05$ to $1.64 \mathrm{E}-04 \mathrm{~m} \cdot \mathrm{s}^{-1}$. The changeability of the discussed parameters during the spring series of measurements is shown in Fig. 4.

During the summer series of measurements the obtained variability of specific discharge $q_{d}$ was higher compared to the spring series. The highest value equal to $5.11 \mathrm{E}-03 \mathrm{~cm}^{3} \cdot \mathrm{s}^{-1} \cdot \mathrm{cm}^{-2}$ was observed at the eleventh measurement point at the PM_6 profile, then the lowest value equal to $5.47 \mathrm{E}$ $-05 \mathrm{~cm}^{3} \cdot \mathrm{s}^{-1} \cdot \mathrm{cm}^{-2}$ at the twentieth point at the PM_11 profile. The largest specific discharge evenness $q_{d}$ was observed at the PM_1, PM_5 and PM_14 profiles. All of them were located at straight stretches, with relatively levelled shapes of the riverbed. Then the highest variability was observed at the PM_4, PM_6, PM_7 and PM_9 profiles. All these profiles were located at curvy stretches, within meanders, where the river bed varies in shape. During the summer series of measurements, the distribution of hydraulic gradi-
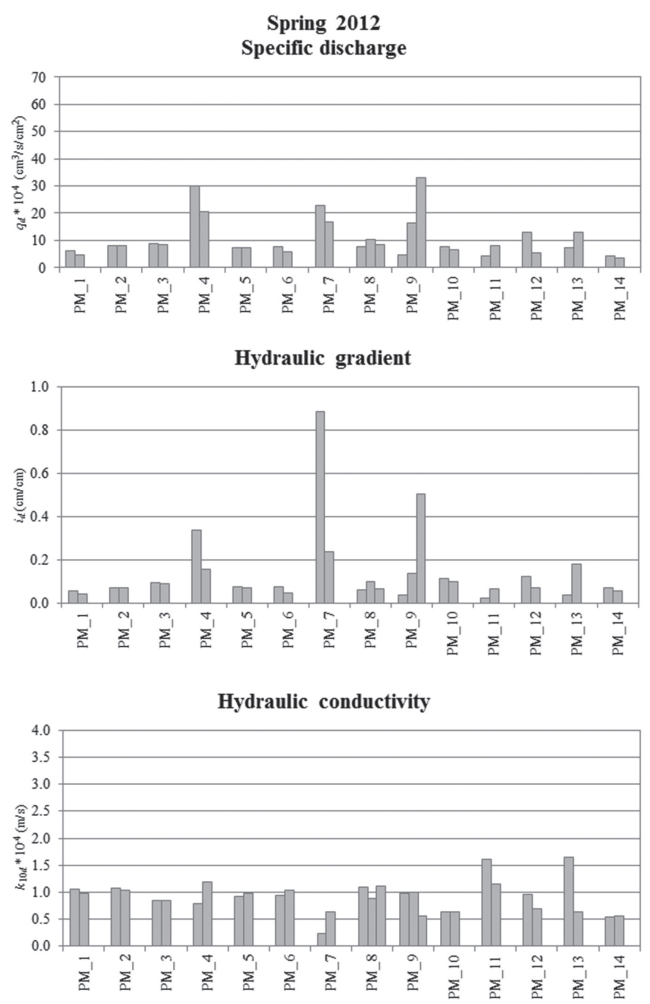

Fig. 4. Results of the spring series of measurements of drainage in the Parsęta River Source: authors' own study. 


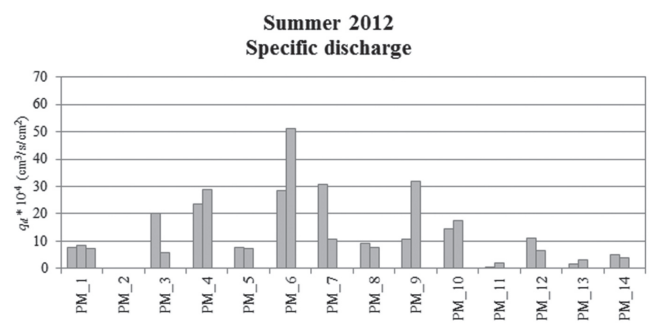

Hydraulic gradient

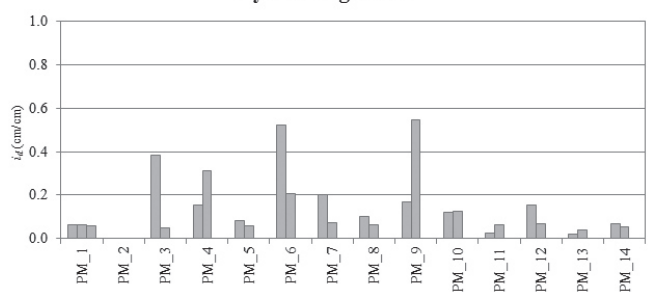

Hydraulic conductivity

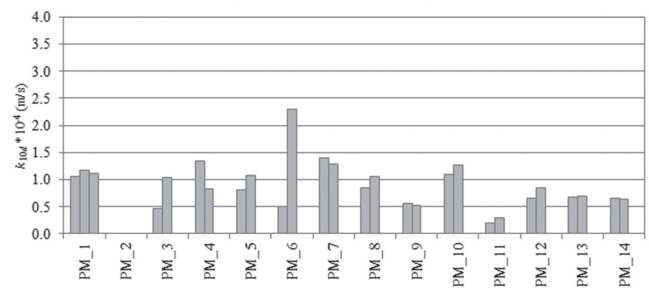

Fig. 5. Results of the summer series of measurements of drainage in the Parsęta River Source: authors' own study. ent values $i_{d}$ also matches the distribution of specific discharge $q_{d}$. The obtained gradient spread is, however, smaller than in spring and ranges from $0.020 \mathrm{~cm}$ to $0.545 \mathrm{~cm}$. In contrast, the variability of hydraulic conductivity $k_{10 d}$ was reported to be by far higher from $2.03 \mathrm{E}-05$ to $2.30 \mathrm{E}-04 \mathrm{~m} \cdot \mathrm{s}^{-1}$. The diversity of the above parameters during the summer series of measurements is shown in Fig. 5.

During the autumn series of measurements the lowest spread of specific discharge $q_{d}$ was obtained when compared to the previous series. The highest value equal to $1.90 \mathrm{E}-03 \mathrm{~cm}^{3} \cdot \mathrm{s}^{-1} \cdot \mathrm{cm}^{-2}$ was observed at the twelfth measurement point at the PM_7 profile, then the lowest value equal to $2.01 \mathrm{E}-04 \mathrm{~cm}^{3} \cdot \mathrm{s}^{-1} \cdot \mathrm{cm}^{-2}$ at the eleventh point at the PM_6 profile. The distribution of hydraulic gradient values $i_{d}$ - to a lesser extent - reflects the distribution of specific discharge $q_{d}$. The obtained spread of gradient is the

lowest out of the three series and ranges from $0.045 \mathrm{~cm}$ to $0.430 \mathrm{~cm}$. During the autumn series of measurements the highest variability of hydraulic conductivity $k_{10 d}$ was observed. The spread of the obtained values ranged from 7.39E-06 to $2.33 \mathrm{E}-04 \mathrm{~m} \cdot \mathrm{s}^{-1}$. The diversity of the above parameters during the autumn series of measurements is shown in Fig. 6.

Analyzing the temporal variability of specific discharge $q_{d}$, at various times of the year, the following regularities and differences were reported. During the autumn series of measurements specific discharge was the lowest at most of the morphometric profiles. By contrast, during the summer series of measurements it was the highest at most of the morphometric profiles. The profiles - located at straight sections of the river and having levelled transverse cross-section of their beds - were characterized by lower and fairly levelled specific discharge 
values $q_{d}$ The above dependency is explicitly perceptible at the following profiles: PM_1, PM_5, PM_11 and PM_14. The low and levelled values of specific discharge $q_{d}$ correlate with low and levelled hydraulic gradient values $i_{d}$ In contrast, at the profiles located within a meander, where the riverbed is modified by fluvial processes, especially lateral erosion and river accumulation (Klimaszewski 1978), specific discharge values are characterized by higher diversity, both within an individual profile and at different times of the year. The PM_4, PM_6, PM_7, PM_9 and PM_10 profiles can be given as examples. At these profiles the specific discharge values are higher at points located within areas where intensive erosion takes place and lower at points located within sediment accumulative areas. The above dependency is best seen at the PM_7 profile. This profile is located at the beginning of the largest meander within the examined section of the Parsęta River. The riverbed at this profile represents a typical shape of erosive and accumulation meanders (Klimaszewski 1978). Its left bank is within the largest river main current where lateral erosion is the most intense. In contrast, the right bank, being a meander deposition area, is dominated by river accumulation.

In all the three measurement series, two measurements of drainage were conducted at the PM_7 profile. The measurement points were placed at a distance of $1 \mathrm{~m}$ from one another. The first point starting from the left bank was located within the largest deepening of the erosive area; another one - within the shallower accumulative area. Within the erosive area of the river groundwater inflow was significantly higher. This occurrence is certainly caused by high hydraulic gradient, which results from the elevation of bottom sediments from within this area by 
the river which, in turn, causes its deepening. Moreover, when finer sediments are washed out within the erosive areas, thicker fractions characterized by higher permeability are left. The landforms in the immediate vicinity of this meander matters as well. The meander front, at which the PM_7 profile is located, cuts into an escarpment at a height of several meters (Photo 2). Taking into consideration that in most cases the surface of the groundwater table reflects the land relief (Pazdro, Kozerski 1990), it can be assumed that the water table at the left bank is higher than the one at the right bank, which further increases groundwater inflow into the river from the left bank. In contrast, within the accumulative areas, lower hydraulic gradient and lower permeability of sediments can be found due to the dominating presence of finer fractions. Moreover, this river bank is adjacent to some flat area. Within such areas groundwater inflow into the river is smaller.

As a result of all the three series of field measurements, in total, eighty five point measurements were conducted on the drainage of groundwater in the Parsęta River. For each series, its measurements were sub-divided into three groups: points located within meander erosive areas (dark grey), points located within meander accumulative areas (light grey) and points located at straight sections of the river (white). The following average values were calculated for each group of points: specific discharge $q_{d}$, hydraulic gradient $i_{d}$ and hydraulic conductivity $k_{10 d^{*}}$ The obtained results were compared to the average values obtained for all the measurements in the series. On these grounds, percentage share of groundwater inflow of the Parsęta River at the test section was calculated taking into consideration the location of measuring points lin each of the three groups.

\section{Summary and conclusions}

During all the series of measurements the largest groundwater inflow into the Parsęta River, expressed through specific discharge $q_{d}$, was found within meander erosive areas. During the spring and summer series it accounted for over $150 \%$ of average supplies, but during the autumn series - over $120 \%$. Within meander accumulative areas during the spring and autumn series, groundwater supplies of the river were close to the average, and during the summer series they significantly exceeded it reaching more than $130 \%$ of the average level. The lowest value of groundwater supplies of the river occurred at the measuring points located at straight sections.

The distribution of hydraulic gradient $i_{d}$ follows a similar path. The highest values of hydraulic gradient were found within meander erosive areas at which, at each series of measurements, these values far exceeded the average gradient. The lowest gradients were found for straight sections. 
In case of hydraulic conductivity $k_{d}$, during all the series of measurements, the highest values (in excess of $100 \%$ of the average) were recorded at points located within meander accumulative areas. Hydraulic conductivity is the quotient of specific discharge and hydraulic gradient (Equation 5 ) and depends on depths of groundwater, water levels in the river, land relief of the river valley / the riverbed as well as types of bottom sediments.

On an annual basis, the largest

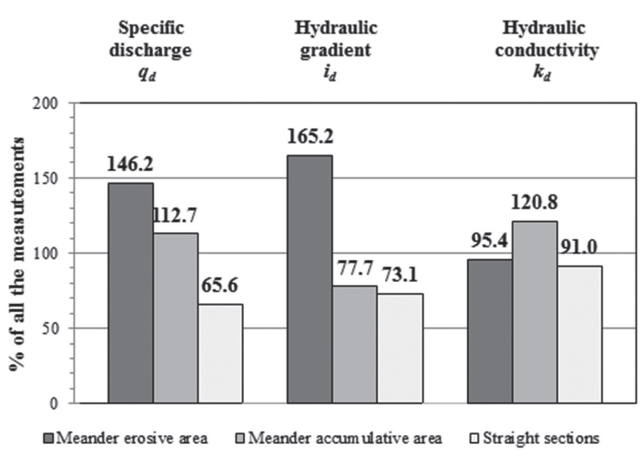

Fig. 7. Average annual values of measured parameters for three groups of measuring points (three groups)

Source: authors' own study. drainage of groundwater takes place within meander erosive areas where it reaches $146.2 \%$ of the average value for the analysed section of the Parsęta River. Within meander accumulative areas, the drainage is $112.7 \%$, which is close to the average value. Then at straight sections the drainage of groundwater is the smallest at $65.6 \%$ of the average level (Fig. 7).

The above-specified research studies conducted in the Parsęta valley allowed to determine the spatial variability of drainage of groundwater by the Parseta River within the tested sections. In addition, they confirmed the usefulness of the new measuring devices to identify and determine the status and conditions of groundwater inflow into the river.

\section{Acknowledgements}

This research has been partly funded by the National Science Centre projects:

1. N N304 274340 entitled: "The current state and conditions of the natural environment within the selected areas of Western Pomeranian region affected by climatic changes and increased anthropopressure".

2. NCN 2011/01/N/ST10/02012 entitled: "Identification of filtration parameters of bottom formations in the area of surface water and groundwaters synergy".

3. NCN 2015/17/8/ST10/01833 entitled: "Conditions of the daily fluctuations in the levels of water in rivers and springs taking into account the influence of hyporheic zone". 


\section{References}

Baxter C., Hauer F.R., Woessner W.W., 2003, Measuring groundwater-stream water exchange: New techniques for installing minipiezometers and estimating hydraulic conductivity, Transactions of the American Fisheries Society, 132, 493-502.

Brodie R.S., Baskaran S., Ransley T., Spring J., 2009, The seepage meter: Progressing a simple method of directly measuring water flow between surface water and groundwater systems, Australian Journal of Earth Sciences, 56, 1, 3-11.

Choiński A., 1998, Warunki obiegu wody w dorzeczu Parsęty, [in:] A. Kostrzewski (ed.), Funkcjonowanie geoekosystemów zlewni rzecznych. 1. Środowisko przyrodnicze dorzecza Parsęty, stan badań, zagospodarowanie, ochrona, Wydawnictwo Uczelniane Politechniki Koszalińskiej, Koszalin, 36-51.

Chudziak Ł., 2014, Identyfikacja parametrów filtracyjnych w strefie wspótdziatania wód powierzchniowych i podziemnych, Bogucki Wyddawnictwo Naukowe, Poznań.

Isiorho S.A., Meyer J.H., 1999, The effects of bag type and meter size on seepage meter measurements, Ground Water, 37,3, 411-413.

Janik B., Kowalik A., Marciniak M., 1989, Pomiary infiltrometryczne jako podstawa oceny udziatu wód ræecznych w zasilaniu ujęcia drenażowego Reda-Pieles«ewo, Przegląd Geologiczny, 10, 511-516.

Kalbus E., Reinstorf F., Schirmer M., 2006, Measuring methods for groundwater-surface water interactions: A review, Hydrology and Earth System Science, 10, 873-887.

Kaniecki A., 1994, Charakterystyka hydrologiczna górnej Parsęty, [in:] A. Kostrzewski (ed.), Zintegrowany Monitoring Środowiska Przyrodničego. Stacja Bazowa Storkowo, Biblioteka Monitoringu Środowiska, Warszawa, 97-104.

Klimaszewski M., 1978, Geomorfologia, PWN, Warszawa.

Kostrzewski A., Mazurek M., Zwoliński Z., 1994, Dynamika transportu fluwialnego górnej Parsęty jako odbicie funkcjonowania systemu zlewni, Stowarzyszenie Geomorfologów Polskich, Poznań.

Marciniak M., Chudziak Ł., 2015, Nowa metoda pomiaru wspótczynnika filtracji osadów dennych, Przegląd Geologiczny, 63, 10 (2), 919-925.

Murdoch L.C., Kelly S.E., 2003, Factors affecting the performance of conventional seepage meters, Water Resources Research, 39, 6, SWC 2-1 - SWC 2-10.

Pazdro Z., Kozerski B., 1990, Hydrogeologia ogólna, Wydawnictwo Geologiczne, Warszawa. Pociask-Karteczka J. (ed.), 2003, Zlewnia, wtaściwości i procesy, Wydawnictwo IGiGP UJ, Kraków.

Rosenberry D.O., Morin R.H., 2004, Use of an electromagnetic seepage meter to investigate temporal variability in lake seepage, Ground Water, 42, 1, 68-77.

Rosenberry D.O., 2008, A seepage meter designed for use in flowing water, Journal of Hydrology, 359, 118-130. 
Sanders L.L., 1998, A manual of field hydrogeology, Prentice Hall, New Jersey.

Szpikowski J., Domańska M., Kruszyk R., Szpikowska G., Tylkowski J., 2006, Stacja baæowa Storkowo, [in:] A. Kostrzewski (ed.), Stan, przemiany i funkcjonowanie geoekosystemów Polski w latach 1994-2004 na podstawie Zintegrowanego Monitoringu Środowiska Przyrodnicæego, Biblioteka Monitoringu Środowiska, Warszawa, 93-136.

Winter T.C., LaBaugh J.W., Rosenberry D.O., 1988, The design and use of a hydraulic potentiomanometer for direct measurement of differences in hydraulic head between groundwater and surface water, Limnology and Oceanography, 33, 5, 1209-1214.

Wolf S.H., LaChance J.C., Wolf L.J., 1991, Techniques for monitoring flux and transport between ground water and surface water systems, Ground Water Management, 5, 179-192.

\author{
Marek Marciniak \\ Adam Mickiewicz University in Poznań \\ Institute of Physical Geography and Environmental Planning \\ 10 Bogumita Krygowskiego Str., 61-680 Poznań, Poland \\ e-mail:mmarc@amu.edu.pl \\ Łukasz Chudziak \\ Secondary School Complex No. 2 for them. Charles de Gaulle in Poznan \\ 27 Tarnowska Str., 61-323 Poznań, Poland \\ e-mail:chuudzik@op.pl
}


